\title{
Komparasi pembelajaran SAVI dan REACT pada kemampuan pemecahan masalah siswa kelas-viii materi kubus dan balok
}

\section{Andriawan Meka Siswoyuono, Bambang Eko Susilo ${ }^{1}$}

\begin{abstract}
Abstrak: Penelitian ini bertujuan untuk mengetahui hasil komparasi antara model pembelajaran SAVI dan REACT terhadap kemampuan pemecahan masalah siswa. Penelitian ini merupakan penelitian eksperimen dengan post test-only control group design. Populasi penelitian ini adalah siswa kelas VIII SMP Negeri 1 Ungaran tahun ajaran 2013/2014 dengan sampel diambil secara cluster random sampling, terpilih tiga kelas sampel dimana setiap kelas terdiri dari 24 siswa. Kelas eksperimen 1 diberi perlakuan dengan model pembelajaran SAVI, kelas eksperimen 2 diberi perlakuan dengan model pembelajaran REACT, dan kelas kontrol dengan model pembelajaran Direct Instruction. Pengambilan data dilakukan dengan metode observasi untuk mengetahui aktivitas siswa dan guru, dan metode tes untuk mengetahui kemampuan pemecahan masalah siswa yang kemudian dianalisis dengan uji proporsi, uji perbedaan rata-rata, dan uji lanjut Tukey. Hasil penelitian ini menunjukkan bahwa tidak terdapat perbedaan signifikan kemampuan pemecahan masalah antara kelas eksperimen 1 dan 2. Jadi, baik model pembelajaran SAVI maupun REACT sama-sama efektif dalam mengembangkan kemampuan pemecahan masalah siswa.
\end{abstract}

Kata kunci : Kemampuan Pemecahan Masalah; Komparasi; SAVI; REACT

\begin{abstract}
This study aims to evaluate the result of comparison between SAVI and REACT learning model toward problem-solving ability of students. This research is an experimental research with a post test-only control group design. The population of this research is the eighth grade students of Junior High School 1 Ungaran 2013/2014 academic year. Samples are taken by random cluster sampling technique which select three sample classes where each class consists of 24 students. The experimental class 1 was treated with SAVI learning model, the experimental class 2 was treated with REACT learning model, and a control class was taught with the Direct Instruction learning model. Data is collected by observation method to determine the activity of students and teacher, and test methods to determine the students' problem solving abilities are then analyzed by the proportion test, the mean difference test, and Tukey's test. The results
\end{abstract}

\footnotetext{
${ }^{1}$ Universitas Negeri Semarang, Semarang, Indonesia, andriawanmekas@yahoo.com
} 
of this study indicate that there is no significant difference between the problem solving ability of students in the experimental class 1 and 2. Thus, both SAVI and REACT learning models are effective to improve students' problem solving abilities.

Keywords: Problem-Solving Ability; Comparative; SAVI; REACT

\section{A. Pendahuluan}

BSNP (2006) mengemukakan bahwa matematika merupakan ilmu universal yang mendasari perkembangan teknologi modern, mempunyai peran penting dalam berbagai disiplin ilmu dan memajukan daya pikir manusia. Matematika merupakan ilmu yang berperan penting dalam dunia pendidikan karena matematika merupakan salah satu ilmu dasar bagi pengembangan dasar ilmu yang lain, sehingga tanpa matematika perkembangan ilmu pengetahuan dan teknologi tidak mengalami kemajuan yang berarti. Matematika juga membekali siswa dengan kemampuan berpikir kritis, logis, analitis, kritis, dan sistematis.

Matematika adalah suatu alat untuk mengembangkan cara berfikir. Karena itu matematika sangat diperlukan baik untuk kehidupan seharihari maupun dalam menghadapi kemajuan IPTEK sehingga matematika perlu dibekalkan kepada setiap peserta didik sejak SD, bahkan sejak TK (Hudojo, 2005). Oleh karena itu, matematika merupakan ilmu yang penting untuk diajarkan di sekolah.

Cornelius dalam Abdurrahman (2003) menyatakan terdapat lima alasan perlunya belajar matematika, antara lain karena matematika merupakan (1) sarana berpikir yang jelas dan logis, (2) sarana untuk memecahkan masalah kehidupan sehari-hari, (3) sarana mengenal polapola hubungan dan generalisasi pengalaman, (4) sarana untuk mengembangkan kreativitas, dan (5) sarana untuk meningkatkan kesadaran terhadap perkembangan budaya. Oleh karena itu, salah satu kemampuan matematika yang penting untuk dimiliki oleh siswa adalah kemampuan pemecahan masalah.

Dalam memecahkan masalah-masalah matematika, siswa akan mendapatkan cara berpikir, pembiasaan dalam ketekunan dan rasa ingin tahu, dan rasa percaya diri dalam situasi berbeda-beda yang akan membantu siswa dalam kehidupan di luar kelas (NCTM, 2000). Rajagukguk 
(2011) mengungkapkan, pemecahan masalah merupakan bagian yang sangat penting karena dalam proses pembelajaran maupun penyelesaiannya, siswa dimungkinkan memperoleh pengalaman menggunakan pengetahuan serta ketrampilan yang sudah dimiliki untuk diterapkan pada pemecahan masalah. Pemecahan masalah menjadi fokus dalam pembelajaran matematika karena dalam panduan standar isi mata pelajaran matematika disebutkan bahwa pemecahan masalah fokus dalam pembelajaran matematika (BSNP, 2006).

Materi Kubus dan Balok merupakan materi pokok pelajaran matematika kelas VIII SMP pada semester genap. Kriteria Ketuntasan Minimal (KKM) untuk mata pelajaran matematika di SMP Negeri 1 Ungaran adalah 80 dan ketuntasan klasikalnya adalah $80 \%$. Berdasarkan hasil ulangan harian materi Kubus dan Balok kelas VIII tahun pelajaran 2012/2013, dari seluruh siswa kelas VIII didapatkan rata-rata nilai 78 sedangkan siswa yang belum tuntas atau belum mencapai KKM sebesar $42,67 \%$. Hal ini menunjukkan bahwa nilai ulangan harian siswa belum mencapai KKM dan jumlah siswa yang tuntas hanya sebesar 57,33 \% jauh di bawah batas minimal ketuntasan klasikal yaitu $80 \%$. Hasil wawancara dengan guru yang bersangkutan pada bulan Januari 2014, diperoleh informasi bahwa rendahnya nilai ulangan harian tersebut disebabkan oleh kemampuan pemecahan masalah siswa rendah yang dimungkinkan dikarenakan oleh kemampuan pemahaman konsep siswa yang masih rendah.

Berdasarkan hasil observasi yang dilakukan peneliti di SMP Negeri 1 Ungaran pada bulan Januari tahun 2014, pembelajaran yang dilakukan oleh guru matematika di sekolah menggunakan model pembelajaran Direct Instruction, sama dengan yang dikemukakan Slavin (dalam Iru dan Arihi, 2012) yaitu menginformasikan tujuan dan orientasi belajar, mereview pengetahuan dan keterampilan prasyarat, menyampaikan materi pelajaran, melaksanakan bimbingan, memberi latihan, menilai kinerja siswa dan memberikan umpan balik, dan memberikan latihan mandiri.

Iru dan Arihi (2012) menjelaskan bahwa keterbatasan model pembelajaran Direct Instruction adalah model pembelajaran Direct Instruction melibatkan banyak komunikasi satu arah, guru sulit untuk mendapatkan umpan balik mengenai pemahaman konsep siswa. Hasil 
observasi juga menunjukkan dalam pembelajaran yang dilaksanakan oleh guru di dalam kelas, siswa lebih sering pasif dalam pembelajaran terlebih khusus dalam menemukan suatu konsep yang baru. Hal ini menyebabkan pemahaman siswa terhadap konsep tersebut tidak bisa maksimal. Guru yang dominan dalam pembelajaran juga menyebabkan siswa menjadi kurang antusias dan pasif dalam kegiatan belajar mengajar. Oleh karena itu, siswa mengalami kesulitan ketika guru memberikan masalah-masalah untuk diselesaikan karena konsep yang diajarkan oleh guru masih belum dipahami sepenuhnya oleh siswa.

Mengingat begitu pentingnya pemahaman konsep yang baik dari siswa, maka diperlukan inovasi model pembelajaran matematika di dalam kelas. Pembelajaran yang dimaksudkan adalah pembelajaran yang melibatkan siswa aktif dan efektif di dalamnya, seperti pembelajaran SAVI (Somatic, Auditory, Visual, Intellectual) yang proses belajarnya melibatkan indra pada tubuh yang mendukung pembelajaran, belajar dengan bergerak aktif secara fisik, dengan memanfaatkan indra sebanyak mungkin, dan membuat seluruh tubuh atau pikiran terlibat dalam proses belajar sehingga dapat meningkatkan pemahaman konsep siswa (Rizal, 2013). Dengan peningkatan pemahaman konsep diharapkan kemampuan pemecahan masalah siswa juga akan lebih baik karena siswa memperoleh pembelajaran yang bermakna dengan terlibat aktif dalam proses pembelajaran. Rajagukguk (2011) berpendapat bahwa banyaknya siswa yang tidak mampu menyelesaikan soal dikarenakan proses pembelajaran yang kurang bermakna sehingga menyebabkan rendahnya kemampuan siswa dalam memecahkan masalah.

Dalam mewujudkan pembelajaran yang bermakna tersebut, Meier (2003) menyarankan kepada guru untuk menggunakan model pembelajaran SAVI (Somatic, Auditory, Visual, Intellectual) sebagai upaya meningkatkan kemampuan pemecahan masalah siswa. Menurut Suyatno (2009), model pembelajaran SAVI adalah pembelajaran yang memanfaatkan semua alat indera yang dimiliki siswa. De Porter (2005) menyatakan bahwa SAVI adalah model pembelajaran yang menggabungkan gerak fisik dengan aktivitas intelektual dan penggunaan semua alat indera yang bertujuan untuk menekankan bahwa proses belajar akan berpengaruh besar terhadap pembelajaran. Melalui model pembelajaran SAVI dimana siswa diajak untuk aktif bergerak dan berpikir 
dalam menemukan suatu konsep dengan bantuan alat peraga akan mengakibatkan pemahaman siswa terhadap konsep yang diajarkan lebih maksimal.

Salah satu jenis model pembelajaran lain yang digunakan dalam dunia pendidikan di Indonesia adalah model pembelajaran REACT (Relating, Experiencing, Applying, Cooperating, Transferring). CORD (Center for Occupational Research and Development) (1999) menyampaikan model pembelajaran yang merupakan pengembangan dari model pembelajaran kontekstual yang disingkat REACT, yaitu relating, experiencing, applying, cooperating, dan transferring. REACT ini merupakan pembelajaran yang tepat untuk menciptakan pembelajaran matematika yang melibatkan siswa lebih aktif di dalamnya. Akronim REACT menjelaskan aspek-aspek yang harus dilaksanakan dalam kegiatan pembelajaran yakni menghubungkan (relating), mengeksplorasi hingga menemukan (experiencing), penerapan (applying), bekerja sama (cooperating), dan transfer pengetahuan (transferring).

Melalui model pembelajaran REACT dimana siswa diajak untuk membangun atau menemukan suatu konsep yang baru dari konsepkonsep yang sudah mereka pahami sebelumnya atau dari permasalahan di dunia nyata yang selanjutnya diterapkan dalam permasalahan kehidupan sehari-sehari dengan diskusi bersama teman-temannya, pemahaman siswa tentang konsep kubus dan balok diharapkan akan lebih mudah.

Berdasarkan uraian tersebut, peneliti melakukan penelitian berupa komparasi pembelajaran SAVI dan REACT pada kemampuan pemecahan masalah siswa kelas-VIII materi kubus dan balok. Adapun tujuan utama dalam penelitian ini adalah untuk mengetahui hasil komparasi antara model pembelajaran SAVI dan REACT terhadap kemampuan pemecahan masalah siswa dengan rumusan masalah (1) apakah kemampuan pemecahan masalah siswa kelas VIII materi kubus dan balok melalui model pembelajaran SAVI (Somatic, Auditory, Visual, Intellectual) mencapai ketuntasan belajar, (2) apakah kemampuan pemecahan masalah siswa kelas VIII materi kubus dan balok melalui model pembelajaran REACT (Relating, Experiencing, Applying, Cooperating, Transferring) mencapai ketuntasan belajar, dan (3) apakah terdapat perbedaan signifikan kemampuan pemecahan masalah siswa kelas VIII materi kubus dan balok antara model pembelajaran SAVI (Somatic, 
Auditory, Visual, Intellectual), model pembelajaran REACT (Relating, Experiencing, Applying, Cooperating, Transferring), dan model pembelajaran Direct Instruction.

\section{B. Metode Penelitian}

Jenis penelitian yang dilaksanakan adalah penelitian eksperimen. Desain penelitian yang digunakan adalah post test-only control group design untuk mengetahui kemampuan pemecahan masalah siswa. Evaluasi dilakukan di kelompok eksperimen dan di kelompok kontrol dengan soal tes yang sama.

Tabel 1. Desain Penelitian

\begin{tabular}{|l|l|c|}
\hline \multicolumn{1}{|c|}{ Kelompok } & \multicolumn{1}{c|}{ Perlakuan } & Evaluasi \\
\hline Kelas Eksperimen 1 & Model Pembelajaran SAVI & Tes \\
\hline Kelas Eksperimen 2 & Model Pembelajaran REACT & Tes \\
\hline Kelas Kontrol & $\begin{array}{l}\text { Model Pembelajaran Direct } \\
\text { Instruction }\end{array}$ & Tes \\
\hline
\end{tabular}

Populasi dalam penelitian ini adalah siswa kelas VIII SMP Negeri 1 Ungaran tahun ajaran 2013/2014. Dalam penelitian ini ada tiga kelompok sampel. Satu kelompok siswa tergabung dalam kelompok eksperimen 1, yaitu kelompok siswa kelas VIII C yang diberi perlakuan berupa model pembelajaran SAVI; satu kelompok siswa tergabung dalam kelompok eksperimen 2, yaitu kelompok siswa kelas VIII D yang diberi perlakuan berupa model pembelajaran REACT; dan satu kelompok siswa tergabung dalam kelompok kontrol, yaitu kelompok siswa kelas VIII E yang diberi perlakuan berupa model pembelajaran Direct Instruction.

Pengambilan sampel dalam penelitian ini dilakukan secara cluster random sampling. Hal ini dilakukan dengan pertimbangan bahwa kedudukan siswa dalam kelas diterapkan secara acak tanpa melihat peringkat nilai, jenis kelamin, dan golongan, sehingga siswa sudah tersebar secara acak dalam kelas yang ditentukan. Selain itu, banyaknya siswa dalam kelas sama, siswa mendapat materi berdasarkan kurikulum yang sama, siswa mendapat waktu pelajaran yang sama, tidak ada kelas unggulan dan buku sumber yang digunakan sama. Selain itu, dalam proses pembelajaran guru mengajarkan materi yang sama dengan model 
pembelajaran yang sama. Peneliti juga telah menguji Data Nilai Ulangan Akhir Matematika Semester Gasal Tahun Ajaran 2013/2014, setelah diuji homogenitas dan normalitas diperoleh kesimpulan bahwa populasi berdistribusi normal dan memiliki varians yang homogen. Variabel yang diukur dalam penelitian ini adalah kemampuan pemecahan masalah siswa setelah diberi perlakuan berupa model pembelajaran SAVI dan REACT pada kelompok eksperimen serta pembelajaran Direct Instruction pada kelompok kontrol.

Adapun langkah-langkah yang dilakukan dalam penelitian ini, yaitu:

1. Menentukan populasi penelitian yakni siswa kelas VIII SMPN 1 Ungaran;

2. Meminta kepada guru, nilai ulangan akhir semester (UAS) gasal siswa kelas VIII, data tersebut diuji normalitas dan homogenitas. Setelah dianalisis, diketahui bahwa siswa kelas VIII berawal dari keadaan awal yang berdistribusi normal dan homogen;

3. Menentukan sampel penelitian menggunakan teknik cluster random sampling. Diperoleh tiga kelas sampel yaitu kelas VIII C sebagai kelas eksperimen 1, kelas VIII D sebagai kelas eksperimen 2, dan kelas VIII E sebagai kelas kontrol;

4. Menguji kesamaan rata-rata nilai ulangan akhir semester gasal kelas eksperimen 1, kelas eksperimen 2 dan kelas kontrol. Setelah dianalisis menggunakan uji kesamaan rata-rata (uji t), diketahui bahwa kelas ekperimen 1 yaitu kelas VIII C, kelas eksperimen 2 yaitu kelas VIII D, dan kelas kontrol yaitu kelas VIII E mempunyai rata-rata yang tidak berbeda;

5. Menentukan langkah-langkah pembelajaran yang akan dilakukan dengan model pembelajaran SAVI (Somatic, Auditory, Visual, Intellectual), REACT (Relating, Experiencing, Applying, Cooperating, Transferring), dan Direct Instruction yang dituangkan dalam RPP;

6. Membuat instrumen penelitian meliputi menyusun kisi-kisi tes dan membuat instrumen tes uji coba berdasarkan kisi-kisi yang telah disusun;

7. Melaksanakan uji coba instrumen penelitian yang telah dibuat pada kelas uji coba yakni kelas VIII F;

8. Menganalisis data hasil instrumen tes uji coba untuk mengetahui taraf kesukaran, daya pembeda soal, validitas dan reliabilitas butir soal; 
9. Menetapkan instrumen penelitian yang akan digunakan;

10. Mengamati proses pembelajaran pada kelas eksperimen dan kelas kontrol. Siswa pada kelas eksperimen menggunakan model pembelajaran SAVI (Somatic, Auditory, Visual, Intellecual) dan REACT (Relating, Experiencing, Applying, Cooperating, Transferring). Sedangkan siswa pada kelas kontrol menggunakan model pembelajaran Direct Instruction. Pada kelas eksperimen pembelajaran dipandu oleh peneliti, sedangkan pada kelas kontrol dipandu oleh guru pengampu mata pelajaran matematika pada kelas tersebut;

11. Melaksanakan tes pada dua kelas eksperimen dan kelas kontrol;

12. Mengumpulkan data-data yang diperlukan dalam penelitian pada sampel;

13. Menganalisis atau mengolah data yang telah dikumpulkan dengan metode yang telah ditentukan; dan

14. Menyusun dan melaporkan hasil penelitian.

\section{Hasil dan Pembahasan}

Penelitian yang dilaksanakan menggunakan siswa dari tiga kelas yaitu kelas VIII-E (kelas kontrol), kelas VIII-D (kelas eksperimen 2), dan kelas VIIIC (kelas eksperimen 1). Variabel yang diteliti adalah kemampuan pemecahan masalah siswa pada materi pokok kubus dan balok pada siswa kelas VIII SMP Negeri 1 Ungaran. Sebelum melaksanakan penelitian, peneliti mengidentifikasi permasalahan yang ada, menentukan materi ajar, merancang kegiatan pembelajaran dengan LKS (Lembar Kerja Siswa) dan alat peraga, menyusun rencana pelaksanaan pembelajaran, membuat lembar pengamatan, dan menyusun instrumen tes kemampuan pemecahan masalah siswa. Materi ajar yang dipilih adalah kubus dan balok kompetensi dasar menghitung luas permukaan dan volum kubus, balok, prisma, dan limas. Selama pelaksanaan penelitian, observer dalam hal ini adalah peneliti dan guru matematika. Guru matematika melakukan pengamatan aktivitas siswa, penggunaan media, dan pelaksanaan pembelajaran pada kelas eksperimen. Sedangkan peneliti melakukan pengamatan aktivitas siswa dan pelaksanaan pembelajaran pada kelas kontrol. 
Berdasarkan hasil analisis tahap awal, diperoleh data yang menunjukkan bahwa kelas yang diambil sebagai sampel dalam penelitian berdistribusi normal, mempunyai varians yang homogen, dan tidak ada perbedaan rata-rata yang signifikan diantara kelas-kelas yang diambil sebagai sampel. Hal ini berarti sampel berasal dari kondisi atau keadaan yang sama yaitu memiliki tingkat pengetahuan yang sama. Sedangkan hasil analisis data akhir diperoleh bahwa data akhir 2 kelas eksperimen dan kelas kontrol berdistribusi normal dan mempunyai varians yang homogen.

Pengujian hipotesis I dilakukan untuk mengetahui apakah kemampuan pemecahan masalah siswa pada materi kubus dan balok dengan model pembelajaran SAVI (Somatic, Auditory, Visual, Intellectual) mencapai ketuntasan belajar. Dari hasil uji t diperoleh nilai $t_{\text {hitung }}=4,53$. Karena $t_{\text {hitung }}=4,53>1,71=t_{\text {tabel }}$ maka $\mathrm{H}_{0}$ ditolak dan $\mathrm{H}_{1}$ diterima. Artinya, siswa yang dikenai pembelajaran SAVI telah mencapai ketuntasan belajar individu. Uji ketuntasan belajar klasikal menggunakan uji proporsi satu pihak. Dari hasil uji proporsi diperoleh nilai $z_{\text {hitung }}=1,94$. Karena $z_{\text {hitung }}=$ 1,94 > 1,64 maka $\mathrm{H}_{0}$ ditolak dan $\mathrm{H}_{1}$ diterima. Artinya, siswa yang dikenai pembelajaran SAVI telah mencapai ketuntasan belajar klasikal. Berdasarkan uji hipotesis 1 dapat disimpulkan bahwa hasil belajar siswa dalam aspek kemampuan pemecahan masalah siswa pada kelas eksperimen 1 yang dikenai pembelajaran SAVI mencapai ketuntasan belajar secara individual dan ketuntasan klasikal.

Pengujian hipotesis II dilakukan untuk mengetahui apakah kemampuan pemecahan masalah siswa pada materi kubus dan balok dengan model pembelajaran REACT (Relating, Experiencing, Applying, Cooperating, Transferring) mencapai ketuntasan belajar. Dari hasil uji $\mathrm{t}$ diperoleh nilai $t_{\text {hitung }}=6,76$. Karena $t_{\text {hitung }}=6,76>1,71=t_{\text {tabel }}$ maka $H_{0}$ ditolak dan $\mathrm{H}_{1}$ diterima. Artinya, siswa yang dikenai pembelajaran REACT telah mencapai ketuntasan belajar individu. Dari hasil uji proporsi diperoleh nilai $Z_{\text {hitung }}=1,94$. Karena $Z_{\text {hitung }}=1,94>1,64$ maka $\mathrm{H}_{0}$ ditolak dan $\mathrm{H}_{1}$ diterima. Artinya, siswa yang dikenai pembelajaran REACT telah mencapai ketuntasan belajar klasikal. Berdasarkan uji hipotesis 2 dapat disimpulkan bahwa hasil belajar siswa dalam aspek kemampuan pemecahan masalah siswa pada kelas eksperimen 2 yang dikenai 
pembelajaran REACT mencapai ketuntasan secara individual dan ketuntasan klasikal.

Pengujian hipotesis III menggunakan uji perbedaan rata-rata (ANAVA satu arah) dalam penelitian ini dihitung dengan menggunakan alat bantu program SPSS 16.0. untuk mengetahui apakah terdapat perbedaan signifikan kemampuan pemecahan masalah siswa kelas VIII materi kubus dan balok antara model pembelajaran SAVI, model pembelajaran REACT, dan model pembelajaran Direct Instruction. Diperoleh hasil sebagaimana Gambar 1 berikut.

\section{ANOVA}

$\begin{array}{lrrrrr}\text { Nilai } & \text { Sum of Squares } & \text { df } & \text { Mean Square } & F & \text { Sig. } \\ & 796.444 & 2 & 398.222 & 8.144 & .001 \\ \text { Between Groups } & 3374.000 & 69 & 48.899 & \\ \text { Within Groups } & 4170.444 & 71 & & \\ \text { Total } & & & & \end{array}$

Gambar 1. Hasil Output Uji ANAVA Data Akhir

Diperoleh Sig. $=0,001<0,05$ maka $\mathrm{H}_{0}$ ditolak dan $\mathrm{H}_{1}$ diterima, yang berarti bahwa terdapat perbedaan signifikan dalam kemampuan pemecahan masalah siswa kelas VIII materi kubus dan balok antara pembelajaran SAVI, pembelajaran REACT, dan pembelajaran Direct Instruction. Data selanjutnya diuji melalui uji post hoc/uji lanjut Tukey dan diperoleh hasil seperti dalam Gambar 2.

\section{Multiple Comparisons}

nilai

Tukey HSD

\begin{tabular}{|c|c|c|c|c|c|c|}
\hline \multirow{2}{*}{ (I) kelas } & \multirow{2}{*}{$\begin{array}{l}(\mathrm{J}) \\
\text { kelas }\end{array}$} & \multirow{2}{*}{$\begin{array}{c}\text { Mean Difference } \\
(1-J)\end{array}$} & \multirow[b]{2}{*}{ Std. Error } & \multirow[b]{2}{*}{ Sig. } & \multicolumn{2}{|c|}{$95 \%$ Confidence Interval } \\
\hline & & & & & Lower Bound & Upper Bound \\
\hline \multirow[t]{2}{*}{1} & 2 & -2.667 & 2.019 & .388 & -7.50 & 2.17 \\
\hline & 3 & $5.333^{*}$ & 2.019 & .027 & .50 & 10.17 \\
\hline \multirow[t]{2}{*}{2} & 1 & 2.667 & 2.019 & .388 & -2.17 & 7.50 \\
\hline & 3 & $8.000^{*}$ & 2.019 & .001 & 3.16 & 12.84 \\
\hline \multirow[t]{2}{*}{3} & 1 & $-5.333^{*}$ & 2.019 & .027 & -10.17 & -.50 \\
\hline & 2 & $-8.000^{*}$ & 2.019 & .001 & -12.84 & -3.16 \\
\hline
\end{tabular}

Gambar 2. Hasil Output Uji Lanjut Tukey Data Akhir 
Sig. antara kelas eksperimen 1 (SAVI) dan kelas kontrol (Direct Instruction) adalah 0,027. Karena Sig. $=0,027<0,05$ maka $\mathrm{H}_{0}$ ditolak dan $\mathrm{H}_{1}$ diterima. Artinya, kemampuan pemecahan masalah melalui pembelajaran SAVI lebih baik dari kemampuan pemecahan masalah melalui pembelajaran Direct Instruction. Sig. antara kelas eksperimen 2 (REACT) dan kelas kontrol (Direct Instruction) adalah 0,001. Karena Sig. = $0,001<0,05$ maka $\mathrm{H}_{0}$ ditolak dan $\mathrm{H}_{1}$ diterima. Artinya, kemampuan pemecahan masalah melalui pembelajaran REACT lebih baik dari kemampuan pemecahan masalah melalui pembelajaran Direct Instruction. Dan Sig. antara kelas eksperimen 2 (REACT) dan kelas eksperimen 1 (SAVI) adalah 0,388. Karena Sig. $=0,388>0,05$ maka $\mathrm{H}_{0}$ diterima. Artinya, kemampuan pemecahan masalah melalui pembelajaran REACT tidak lebih dari atau sama dengan kemampuan pemecahan masalah dengan model pembelajaran SAVI atau tidak terdapat perbedaan signifikan kemampuan pemecahan masalah siswa kelas VIII materi kubus dan balok antara model pembelajaran SAVI dan model pembelajaran REACT.

Tidak jauh berbeda dalam pencapaian hasil belajar siswa kelas eksperimen 1, pencapaian hasil belajar pada kelas eksperimen 2 sudah baik. Hal ini salah satunya dikarenakan sintaks/langkah-langkah model pembelajaran REACT. Berdasarkan sintaks model pembelajaran REACT, model pembelajaran tersebut menitik beratkan kepada aktivitas siswa dan permasalahan-permasalahan kontekstual untuk diberikan kepada siswa. Sehingga pemahaman siswa terhadap materi yang diberikan menjadi lebih optimal dan berakibat pada berkembangnya kemampuan pemecahan masalah siswa. Hal tersebut sesuai dengan apa yang diungkapkan Bruner dalam teorinya sebagaimana dikutip dalam Suherman dkk (2003).

Dalam pelaksanaan pembelajaran SAVI pertemuan pertama, manajemen waktu dan pengkondisian siswa yang masih kurang baik. Pembelajaran pada pertemuan pertama memakan banyak waktu pada tahap pengkondisian kelompok, penggunaan alat peraga, dan pada tahap penampilan hasil kerja kelompok. Banyak waktu yang terbuang karena siswa terlalu lama mengkondisikan saat berkelompok, siswa masih bingung penggunaan alat peraga, dan pada saat penampilan hasil kerja kelompok tidak kondusif karena beberapa siswa tidak memperhatikan temannya saat presentasi. Salah satu penyebabnya adalah siswa belum terbiasa dengan model pembelajaran SAVI. Namun, siswa mampu 
beradaptasi secara baik dengan model pembelajaran SAVI ini pada pertemuan-pertemuan berikutnya sehingga pelaksanaan pembelajaran SAVI dapat terlaksana sesuai dengan yang direncanakan dalam Rencana Pelaksanaan Pembelajaran (RPP).

Sedangkan dalam pelaksanaan pembelajaran REACT pada hari pertama, manajemen waktu juga masih kurang baik. Pembelajaran pada pertemuan pertama banyak memakan waktu pada sintaks kerja cooperative. Banyak waktu terbuang dikarenakan siswa masih tidak kondusif dan fokus saat berdiskusi dengan kelompoknya. Hal ini salah satunya disebabkan oleh belum terbiasanya siswa dengan pembelajaran REACT. Tetapi berangsur-angsur pada pertemuan-pertemuan selanjutnya siswa mulai terbiasa dengan model pembelajaran REACT sehingga pelaksanaan pembelajaran REACT dapat terlaksana sesuai dengan yang direncanakan di Rencana Pelaksanaan Pembelajaran (RPP).

Dalam pelaksanaan pembelajaran Direct Instruction, secara umum pembelajaran didominasi oleh guru, siswa kurang aktif dalam proses pembelajaran dikarenakan peran guru yang begitu dominan dalam pembelajaran. Siswa baru terlibat aktif dalam pembelajaran saat guru memberikan soal-soal latihan untuk diselesaikan oleh siswa dan saat siswa menampilkan hasil pekerjaan mereka. Pembelajaran yang dilaksanakan oleh guru dari pertemuan pertama hingga pertemuan terakhir sudah sesuai dengan Rencana Pelaksanaan Pembelajaran (RPP).

Dalam pertemuan pertama hingga pertemuan terakhir pelaksanaan pembelajaran di kelas eksperimen dan kelas kontrol, semua aktivitas siswa telah muncul. Aktivitas yang muncul dalam pengamatan tersebut antara lain aktivitas visual, aktivitas berbicara, aktivitas mendengar, aktivitas menulis, aktivitas menggambar, aktivitas mental, aktivitas motorik, dan aktivitas emosional. Aktivitas visual, aktivitas menulis, aktivitas menggambar, dan aktivitas emosional secara umum sudah muncul pada kelas eksperimen dan kelas kontrol dan tidak ada perbedaaan yang berarti. Namun, aktivitas berbicara, mendengarkan, menulis, dan motorik lebih terlihat pada kelas eksperimen 1 dan kelas eksperimen 2 dibandingkan dengan kelas kontrol. Hal ini terjadi karena pada kelas eksperimen 1 dan eksperimen 2 memiliki sintaks yang menekankan siswa untuk aktif dengan memanipulasi alat peraga dan berdiskusi/bekerja dalam kelompok. Aktivitas berbicara seperti 
mengemukakan pendapat saat berdiskusi dalam kelompok, mengajukan pertanyaan dan menjawab pertanyaan saat fase penampilan hasil. Demikian juga dengan aktivitas mendengarkan, siswa akan terarah untuk mendengarkan penjelasan teman saat berdiskusi dalam kelompok dan penjelasan temaan saat persentasi di depan kelas. Sedangkan aktivitas motorik nampak saat siswa memanipulasi alat peraga untuk menemukan konsep yang baru. Sedangkan pada pembelajaran kelas kontrol tidak terdapat sintaks tentang berdiskusi dan memanipulasi alat peraga.

Berdasarkan post test pemecahan masalah, diperoleh hasil bahwa kemampuan pemecahan masalah siswa sebagian besar mengalami peningkatan meskipun masih ada beberapa siswa yang masih kurang. Hal tersebut dapat dilihat pada Gambar 3 dan 4.

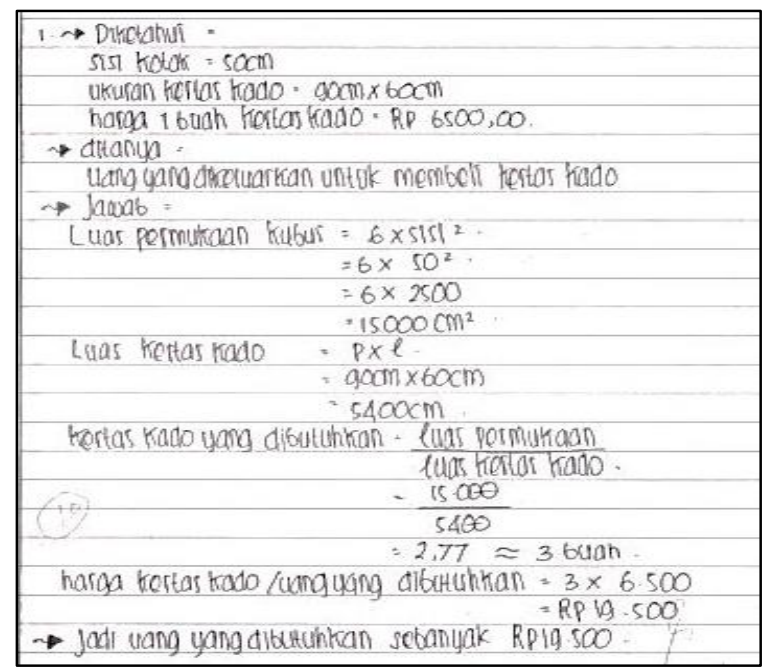

Gambar 3. Contoh Pekerjaan Siswa yang Benar

Berdasarkan contoh pekerjaan siswa tersebut, pada Gambar 3 terlihat bahwa siswa memahami masalah yang diberikan dan mengidentifikasi hal-hal yang diketahui dan ditanyakan dalam soal. Hal ini menunjukkan bahwa siswa sudah melaksanakan langkah pemecahan masalah berdasar langkah pemecahan masalah Polya yang pertama. Selanjutnya siswa menentukan rencana pemecahan masalah dengan tepat dan membuat model matematika dari masalah tersebut. Kemudian, siswa menyelesaikan masalah tersebut sesuai dengan apa yang telah direncanakan sebelumnya dengan lengkap dan runtut. Perhitungan dari 
langkah pertama hingga menemukan jawaban akhir sudah tepat sehingga siswa telah melaksanakan rencana dan strategi pemecahan masalah. Pada setiap akhir pekerjaan, siswa telah menuliskan kesimpulan, meninjau kembali pekerjaan, dan menafsirkan solusi sesuai dengan langkah terakhir pemecahan masalah Polya.

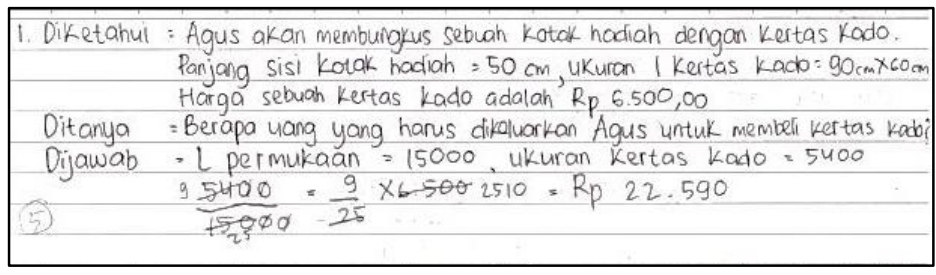

Gambar 4. Contoh Pekerjaan Siswa yang Salah

Sedangkan pada Gambar 4, menunjukkan bahwa meskipun dia memahami masalah yang diberikan dan mengidentifikasi hal-hal yang diketahui dan ditanyakan dalam soal. Tetapi siswa tersebut tidak dapat menentukan rencana pemecahan masalah dengan baik dan jelas sehingga pada akhirnya siswa tersebut tidak dapat menyelesaikan masalah tersebut dengan benar.

Pencapaian hasil belajar siswa kelas eksperimen 1 disebabkan oleh beberapa faktor. Salah satu faktor yang mempengaruhi hal tersebut adalah sintaks model pembelajaran SAVI. Model pembelajaran SAVI menuntut siswa untuk menggunakan seluruh indera yang mereka miliki dalam pembelajaran. Dalam pelaksanaan model pembelajaran SAVI di kelas eksperimen 1 tersebut, siswa sudah terlihat aktif selama pembelajaran melalui pemanipulasian alat peraga, diskusi dan presentasi kelompok sesuai dengan sintaks/langkah-langkah pembelajaran yang ada pada RPP. Dengan demikian, model pembelajaran SAVI yang menitikberatkan kepada aktivitas fisik dan berpikir siswa selama pembelajaran berdampak positif dalam pemahaman siswa terhadap materi yang diajarkan dapat mengembangkan kemampuan siswa dalam memecahkan masalah-masalah yang dimilikinya. Hal tersebut sesuai dengan apa yang diungkapkan Bruner dalam teorinya dimana dalam proses belajar anak sebaiknya diberi kesempatan untuk memanipulasi benda-benda (alat peraga) seperti yang dikutip Suherman dkk. (2003).

Model pembelajaran SAVI dan REACT merupakan model pembelajaran yang sama-sama menitikberatkan kepada aktivitas siswa selama proses pembelajaran berlangsung karena keduanya menekankan 
siswa aktif berpartisipasi selama pembelajaran bukan hanya saat pelatihan dengan soal-soal tetapi juga aktif dalam menemukan konsep yang dipelajari agar siswa menjadi lebih paham dengan materi yang diajarkan. Keduanya terdapat unsur kooperatif dimana siswa saling berdiskusi, saling bertukar pikiran dalam memecahkan masalah yang diberikan. Dengan demikian siswa yang lebih panda dapat membantu temannya yang masih mengalami kesulitan dalam memecahkan masalah dan membantu memberi pemahaman apabila terdapat temannya yang belum paham dengan materi tersebut. Hal ini sesuai dengan teori konstruktivisme yang dinyatakan oleh Vygotsky, seperti yang disampaikan Trianto (2010), yakni proses belajar akan terjadi secara efisien dan efektif apabila anak belajar secara kooperatif dengan anak-anak lain dalam suasana dan lingkungan yang mendukung, dalam bimbingan seseorang yang lebih mampu, guru atau orang dewasa.

Selanjutnya, pada analisis perbedaan kemampuan pemecahan masalah kelas ekperimen 1 dan kelas kontrol, pelaksanaan model pembelajaran SAVI di kelas eksperimen 1, siswa aktif selama pembelajaran dengan menemukan konsep sendiri melalui pemanipulasian alat peraga (hands-on activity), berdiskusi memecahkan masalah yang diberikan oleh guru, dan mempresentasikannya di depan teman-teman yang lain. Siswa yang tidak sedang mempresentasikan pekerjaan mereka juga aktif mendengarkan teman yang lain selama presentasi dan aktif bertanya apabila terdapat hal-hal yang belum dimengerti. Pembelajaran ditutup dengan pemberian kuis oleh guru kepada siswa untuk mengetahui seberapa besar pemahaman siswa selama proses pembelajaran berlangsung.

Sedangkan pada model pembelajaran Direct Instruction, siswa cenderung pasif mendengarkan apa yng dijelaskan oleh guru. Guru menjadi pusat selama pembelajaran dengan memberikan konsep materi dan memberikan contoh soal beserta penyelesaiannya. Siswa baru aktif saat guru memberikan latihan-latihan soal di buku paket ataupun di papan tulis untuk dikerjakan. Sesekali guru memberikan kesempatan kepada siswa untuk menuliskan hasil jawabannya di papan tulis. Secara umum, dalam pelaksanaan model pembelajaran Direct Instruction, guru lebih berperan aktif daripada siswa. 
Berdasarkan analisis pelaksanaan model pembelajaran SAVI dan Direct Instruction, kemampuan pemecahan masalah siswa melalui model pembelajaran SAVI lebih baik dari kemampuan pemecahan masalah siswa melalui model pembelajaran Direct Instruction dikarenakan dalam model pembelajaran SAVI lebih menekankan siswa aktif selama proses pembelajaran melalui penggunaan alat indera yang dimiliki oleh siswa. Hal ini sudah sesuai dengan landasan teori dan hasil analisis statistika dari hasil tes kemampuan pemecahan masalah siswa yang menunjukkan bahwa kemampuan pemecahan masalah siswa melalui model pembelajaran SAVI lebih baik daripada model pembelajaran Direct Instruction.

Analisis perbedaan kemampuan pemecahan masalah siswa antara kelas ekperimen 2 dan kelas kontrol dimana pada pelaksanaan model pembelajaran REACT di kelas eksperimen 2, siswa aktif selama pembelajaran dengan menemukan konsep melalui pemanipulasian alat peraga (hands-on activity) dan memecahkan masalah-masalah kontekstual sederhana secara mandiri. Kemudian, siswa diminta untuk mendiskusikan jawaban mereka secara berkelompok dan mempresentasikannya di depan teman-teman yang lain. Pembelajaran ditutup dengan pemberian masalah kontekstual yang lebih kompleks (kuis) oleh guru kepada siswa untuk mengetahui seberapa besar pemahaman siswa selama proses pembelajaran berlangsung. Sedangkan pada model pembelajaran Direct Instruction sama dengan yang diutarakan sebelumnya pada perbedaan kemampuan pemecahan masalah siswa antara kelas eksperimen 1 dan kelas kontrol. Secara umum, dalam pelaksanaan model pembelajaran Direct Instruction guru lebih berperan aktif daripada siswa.

Berdasarkan hasil analisis pelaksanaan model pembelajaran REACT dan Direct Instruction, kemampuan pemecahan masalah siswa melalui model pembelajaran REACT akan lebih baik daripada kemampuan pemecahan masalah siswa melalui model pembelajaran Direct Instruction dikarenakan dalam model pembelajaran REACT juga lebih menekankan siswa aktif selama proses pembelajaran juga pemberian contoh dan masalah-masalah kontekstual kepada siswa. Hal ini sudah sesuai dengan landasan teori dan juga didukung dengan hasil analisis statistika dari hasil tes kemampuan pemecahan masalah siswa yang menunjukkan bahwa 
kemampuan pemecahan masalah siswa melalui model pembelajaran REACT lebih baik daripada model pembelajaran Direct Instruction.

Sedangkan perbedaan kemampuan pemecahan masalah siswa antara kelas eksperimen 1 dan 2, kemampuan pemecahan siswa melalui model pembelajaran REACT akan lebih baik dari kemampuan pemecahan masalah siswa melalui model pembelajaran SAVI. Hal ini dikarenakan sintaks pada model pembelajaran REACT diasumsikan lebih baik dari model pembelajaran SAVI, yaitu (1) pada model pembelajaran REACT, siswa diajak untuk menemukan sendiri konsep yang baru pada tahap relating dan experiencing serta menyelesaikan penyelesaian masalah sederhana secara mandiri pada tahap applying, sedangkan pada model pembelajaran SAVI, tahap-tahap tersebut dilakukan dalam kelompok; dan (2) secara umum, model pembelajaran REACT menggabungkan antara aktivitas siswa dalam pembelajaran dengan pemberian masalah-masalah kontekstual selama pembelajaran berlangsung, sedangkan model pembelajaran SAVI lebih menekankan pada penggunaan alat indera yang dimiliki siswa selama proses pembelajaran.

Tetapi dalam pelaksanaannya pada model pembelajaran SAVI, waktu berdiskusi dalam kelompok lebih lama dibandingkan pada model pembelajaran REACT, hal ini berpengaruh cukup besar dalam proses pemahaman konsep materi siswa sehingga kemampuan pemecahan siswa pada kelas eksperimen 1 menjadi lebih baik. Siswa dengan waktu yang lebih lama dalam belajar dengan teman sebayanya ternyata membuat siswa lebih mudah memahami materi yang diajarkan dan memecahkan masalah yang diberikan. Hal ini dapat dilihat dari hasil analisis uji statistik yang menunjukkan bahwa tidak ada perbedaan yang signifikan dari kemampuan pemecahan siswa melalui model pembelajaran SAVI dan REACT.

Berdasarkan hasil analisis proses pembelajaran dan uji lanjut hipotesis 3 dapat disimpulkan bahwa terdapat perbedaan signifikan antara kemampuan pemecahan masalah siswa dengan pembelajaran SAVI, pembelajaran REACT, dan pembelajaran Direct Instruction. Sehingga dapat disimpulkan bahwa (1) kemampuan pemecahan masalah siswa melalui pembelajaran SAVI lebih baik dari kemampuan pemecahan masalah siswa melalui pembelajaran Direct Instruction; (2) kemampuan pemecahan masalah siswa melalui pembelajaran REACT lebih baik dari 
kemampuan pemecahan masalah siswa melalui pembelajaran Direct Instruction; dan (3) kemampuan pemecahan masalah siswa melalui pembelajaran REACT tidak berbeda secara signifikan dengan kemampuan pemecahan masalah siswa melalui pembelajaran SAVI.

Sehingga komparasi antara model pembelajaran SAVI dan REACT terhadap kemampuan pemecahan masalah dalam penelitian ini dapat disimpulkan bahwa model pembelajaran SAVI dan REACT sama-sama efektif mengembangkan kemampuan pemecahan masalah siswa. Jadi, baik model pembelajaran SAVI maupun REACT keduanya dapat diterapkan dalam pembelajaran matematika terutama pada materi kubus dan balok.

\section{Simpulan}

Simpulan yang diperoleh dari penelitian ini adalah pembelajaran matematika pada materi kubus dan balok kelas VIII SMP Negeri 1 Ungaran melalui model pembelajaran SAVI dan model pembelajaran REACT samasama efektif dalam mengembangkan kemampuan pemecahan masalah. Hal ini dapat ditunjukkan dengan hasil belajar siswa dalam aspek kemampuan pemecahan masalah pada kelas yang dikenai model pembelajaran SAVI dan model pembelajaran REACT sama-sama mencapai ketuntasan secara individual dan ketuntasan klasikal, kemudian setelah melalui uji statistik, kemampuan pemecahan masalah siswa melalui pembelajaran REACT dan kemampuan pemecahan masalah siswa melalui pembelajaran SAVI tidak berbeda secara signifikan.

\section{Daftar Pustaka}

Abdurrahman, M. (2003). Pendidikan bagi anak berkesulitan belajar. Jakarta: Penerbit Rineka Cipta.

BSNP. (2006) Standar isi untuk satuan pendidikan dasar dan menengah standar kompetensi dan kompetensi dasar SMA/MA. Jakarta: BSNP.

CORD. (1999) Teaching mathematics contextually. The Cornerstone of Tech Prep. CORD Communications, Ins.

De Porter, B. et al. (2005) Quantum teaching. Bandung: Mizan Pustaka.

Iru, L. dan Arihi, L. O. S. (2012) Analisis penerapan: Pendekatan, metode, strategi, dan model-model pembelajaran. Yogyakarta: Multi Presindo.

Hudojo, H. (2005) Pengembangan kurikulum dan pembelajaran matematika. Malang: UM Press. 
Meier, D. (2003) The Accelerated learning handbook: Panduan kreatif dan efektif merancang program pendidikan dan pelatihan, terjemahan Rahmani Astuti. Bandung: Kaifa.

NCTM. (2000) Principles and standards for school mathematics. Reston, VA: NCTM.

Rajagukguk, W. (2011) Upaya meningkatkan kemampuan pemecahan masalah matematika siswa dengan penerapan teori belajar bruner pada pokok bahasan trigonometri di Kelas X Sma Negeri 1 Kualuh Hulu Aek Kanopan T.A. 2009/2010. Medan: Universitas Negeri Medan.

Rizal, S. (2013). Penerapan pendekatan SaVI (Somatis, Auditori, Visual, dan Intelektual) untuk meningkatkan pemahaman konsep teorema Pythagoras siswa kelas VIII-A SMPN 15 Malang. Malang: Program Studi Matematika UM Malang

Suherman dkk. (2003) Strategi pembelajaran matematika kontemporer. Bandung: Universitas Pendidikan Indonesia.

Suyatno. (2009). Menjelajah pembelajaran inovatif. Surabaya: Masmedia Buana Pustaka.

Trianto. (2010) Model pembelajaran terpadu konsep, strategi, dan implementasinya dalam Kurikulum Tingkat Satuan Pendidikan (KTSP). Jakarta: Bumi Aksara. 